\title{
Effect of organic manures, biofertilizers and micronutrients on growth, yield and quality of onion (Allium cepa L.)
}

\author{
ANIL KUMAR, R. B. RAM, SUTANU MAJI*, SACHIN KISHOR, RAHUL YADAV, GOVIND AND \\ KAMAL RAM MEENA \\ Department of Applied Plant Science (Horticulture), Babasaheb Bhimrao Ambedkar University, \\ LUCKNOW (U.P.) INDIA \\ Email: majisutanu@gmail.com; anilkumar38060@gmail.com
}

\begin{abstract}
A field experiment was conducted during the Rabi season to find out the effect of organic manures, biofertilizers and micronutrients on growth, yield and quality of onion cv. NHRDF Red - 2 . There were 13 treatments viz., $\mathrm{T}_{0}$ (Recommended dose of fertilizers), $\mathrm{T}_{1}$ Poultry manure, $\mathrm{T}_{2}$ vermicompost, $\mathrm{T}_{3}$ Azotobacter, $\mathrm{T}_{4} \mathrm{VAM}, \mathrm{T}_{5}$ Azotobacter $+\mathrm{RDF}(50 \%)+$ zinc, $\mathrm{T}_{6}$ Azotobacter + $\mathrm{RDF}(75 \%)+$ zinc, $\mathrm{T}_{7} \mathrm{VAM}+\mathrm{RDF}(50 \%)+$ boron, $\mathrm{T}_{8} \mathrm{VAM}+\mathrm{RDF}(75 \%)+$ boron, $\mathrm{T}_{9} \mathrm{RDF}(25 \%)+\mathrm{VAM}+$ poultry manure $(50 \%)$ + Azotobacter +boron, $\mathrm{T}_{10}\left(\mathrm{RDF}(25 \%)+\mathrm{VAM}+\right.$ vermicompost $(50 \%)+$ Azotobacter +boron, $\mathrm{T}_{11} \mathrm{RDF}(25 \%)+\mathrm{VAM}+$ poultry manure (50\%) Azotobacter + zinc, $\mathrm{T}_{12} \mathrm{RDF}(25 \%)+\mathrm{VAM}+$ vermicompost $50 \%$ Azotobacter + zinc and the experiment was laid out under RBD with three replications. The study clearly revealed that there were significant effects of various treatments on the growth, yield and quality attributes of onion. The number of leaves per plant (12.15), plant height $(73.02 \mathrm{~cm})$, neck thickness $(22.00 \mathrm{~mm})$, bulb length $(6.46 \mathrm{~cm})$, bulb diameter $(7.20 \mathrm{~cm})$, yield $\left(398.36 \mathrm{~kg} / \mathrm{ha}^{-1}\right)$ were recorded maximum in treatment $\mathrm{T}_{12}$ whereas T.S.S ( $\left.14^{\circ} \mathrm{B}\right)$, vitamin $\mathrm{C}(12.11 \mathrm{mg} / 100 \mathrm{~g})$, total sugars $(10.52 \%)$, reducing sugar $(6.23 \%)$ and non-reducing sugar $(4.28 \%)$ were found maximum in $\mathrm{T}_{10}$ treatment as compared to other treatment. However, $\mathrm{T}_{12}$ was good for higher yield improvement and $\mathrm{T}_{10}$ was the best for quality improvement among the all treatments under study, the application of $\mathrm{T}_{12}(\mathrm{RDF}(25 \%)+\mathrm{VAM}+\mathrm{Vermicompost} 50 \%$ Azotobacter +Zinc) may be suggested for successful cultivation of onion in Lucknow.
\end{abstract}

Key Words : Organics, Biofertilizers, Micronutrients, Onion, Yield, Quality

View Point Article : Kumar, Anil, Ram, R. B., Maji, Sutanu, Kishor, Sachin, Yadav, Rahul, Govind and Meena, Kamal Ram (2017). Effect of organic manures, biofertilizers and micronutrients on growth, yield and quality of onion (Allium cepa L.). Internat. J. agric. Sci., 13 (2) : 236241, DOI:10.15740/HAS/IJAS/13.2/236-241.

Article History : Received : 08.02.2017; Revised : 10.04.2017; Accepted : 24.04.2017

\footnotetext{
* Author for correspondence:
} 